慶應義塾大学学術情報リポジトリ

Keio Associated Repository of Academic resouces

\begin{tabular}{|c|l|}
\hline Title & $\begin{array}{l}\text { Comparison of biliary metabolites of androsterone glucuronide and androsterone sulphate in } \\
\text { female rats }\end{array}$ \\
\hline Sub Title & \\
\hline Author & $\begin{array}{l}\text { 松井, 道夫(Matsui, Michio) } \\
\text { 箱崎, 美砂子( Hakozaki, Misako) }\end{array}$ \\
\hline Publisher & 共立薬科大学 \\
\hline Publication year & 1978 \\
\hline Jtitle & $\begin{array}{l}\text { 共立薬科大学研究年報 (The annual report of the Kyoritsu College of } \\
\text { Pharmacy). No.23 (1978. ),p.114- 116 }\end{array}$ \\
\hline JaLC DOI & \\
\hline Abstract & \\
\hline Notes & 抄録 \\
\hline Genre & Technical Report \\
\hline URL & https://koara.lib.keio.ac.jp/xoonips/modules/xoonips/detail.php?koara_id=AN00062898-0000002 \\
& 3-0114 \\
\hline
\end{tabular}

慶應義塾大学学術情報リポジトリ(KOARA)に掲載されているコンテンツの著作権は、それぞれの著作者、学会または出版社/発行者に帰属し、その権利は著作権法によって 保護されています。引用にあたっては、著作権法を遵守してご利用ください。

The copyrights of content available on the KeiO Associated Repository of Academic resources (KOARA) belong to the respective authors, academic societies, or publishers/issuers, and these rights are protected by the Japanese Copyright Act. When quoting the content, please follow the Japanese copyright act. 


\title{
Comparison of Biliary Metabolites of Androsterone Glucuronide and Androsterone Sulphate in Female rats *
}

\author{
Michio MATSUI and Misako HaKozaki \\ 松井道夫, 箱崎美砂子
}

Recent studies from this laboratory demonstrated large variations in biliary metabolites of androsterone in female rats. It was found that some rats excreted androsterone metabolites very rapidly into bile (HE rats), whereas other rats excreted the metabolites at a much slower rate (LE rats). The HE rats formed mainly androsterone glucuronide, while the LE rats converted the androsterone to the monosulphates of androsterone and $3 \alpha, 7 \alpha$ - and $3 \alpha, 11 \beta$-dihydroxy-5 $\alpha$-androstan-17-ones. Siiteri et al. administered ${ }^{3} \mathrm{H}$ labelled androsterone glucuronide to humans and found that this conjugate was rapidly eliminated in urine without undergoing further metabolism. Based on these observations, we speculated that UDP-glucuronyltransferase system might be very active in the $\mathrm{HE}$ rat. Thus, the injected androsterone would be rapidly conjugated with glucuronic acid and excreted in the bile. In contrast, low activity of UDP-glucuronyltransferase or high activity of sulphotransferase in the LE rat might result in the further metabolism of androsterone or androsterone sulphate. However, little is known about the metabolism of androsterone glucuronide and androsterone sulphate in the rat.

In the present paper, $\left[{ }^{3} \mathrm{H}\right]$-androsterone glucuronide and $\left[{ }^{3} \mathrm{H}\right]$-androsterone sulphate were administered intraperitoneally into female rats and the biliary metabolites were isolated and identified by gas chromatography-mass spectrometry.

The injected androsterone glucuronide was excreted rapidly and almost quantitatively in the bile. These results imply that androsterone glucuronide behaves like a metabolic end-product in female rats, as was found in humans. Only $1 \%$ of the injected dose was converted into $5 \alpha$-androstane- $3 \alpha, 17 \beta$-diol monoglucuronide. This conjugate seems to be biotransformed directly from androsterone glucuronide. Androsterone glucuronide was metabolized without hydrolysis of the glucuronic acid moiety to the 3-glucuronide of $5 \alpha$-androstane- $3 \alpha, 17 \beta$-diol by incubation with female rat liver microsomal enzymes fortified with NADPH regenerating system.

Metabolites of androsterone sulphate were much more slowly excreted in the bile than those of androsterone glucuronide. Approximately $7 \%$ of the injected androsterone sulphate was recovered in the bile and the major portion was metabolized to the monosulphate of $3 \alpha, 11 \beta$-dihydroxy-5 $\alpha$-androstan-17-one and disulphates of $5 \alpha$-andr-

*本報告は J. Steroid Biochem., 8, 1243 (1977) に発表。 
ostane- $3 \alpha, 17 \beta$-diol and $3 \alpha, 17 \beta$-dihydroxy-5 $\alpha$-androstan-16-one. There has been accumulating evidence that steroid glucuronides are excreted in rat bile more rapidly than steroid sulphates. Evidence was obtained for the direct conversion of androsterone sulphate to $5 \alpha$-androstane- $3 \alpha, 17 \beta$-diol 3 -sulphate by incubation with female rat liver microsomal enzymes fortified with NADPH regenerating system. Milgrom et al. described that 3-sulphates and 3-glucuronides of androst-5-ene-3 $\beta, 17 \beta$-diol and dehydroepiandrosterone were the substrates for the $17 \beta$-hydroxysteroid-oxido-reductases derived from guinea pig liver supernatant and microsomes and that both oxidation and reduction of $17 \beta$-hydroxy and 17-oxo groups took place at $\mathrm{pH}$ 7.4. Therefore, androsterone sulphate (and glucuronide) and $5 \alpha$-androstane-3 $\alpha, 17 \beta$-diol 3-sulphate (and 3-glucuronide) might be interconvertible in vivo. Recently, Gustafsson et al. described specific $15 \beta$-hydroxylating enzymes active on $\mathrm{C}_{19}$-steroid $17 \beta$-sulphates and $3,17 \beta$-disulphates in female rat liver microsomes. $\mathrm{C}_{19}$-steroid 3 -sulphates were not hydroxylated by the enzymes. In a previous paper, we demonstrated that testosterone sulphate was metabolized in vivo to mono- and disulphates of $5 \alpha$-androstane- $3 \alpha, 17 \beta$-diol and the disulphate of $5 \alpha$-androstane- $3 \alpha, 15 \beta, 17 \beta$-triol in female rats. Thus, mono- and disulphates of $5 \alpha-$ androstane-3 $\alpha, 17 \beta$-diol must be converted into the $15 \beta$-hydroxylated metabolite. In contrast to this, we were unable to isolate the $15 \beta$-hydroxysteroid as a metabolite of androsterone sulphate, though considerable amounts of $5 \alpha$-androstane- $3 \alpha, 17 \beta$-diol $3,17-$ disulphate were present in the bile. $5 \alpha$-Androstane- $3 \alpha, 17 \beta$-diol 3,17 -disulphate should be produced by different pathways from testosterone sulphate (via $5 \alpha$-andrstane- $3 \alpha$, $17 \beta$-diol 17-sulphate) and androsterone sulphate (via $5 \alpha$-androstane-3 $\alpha, 17 \beta$-diol 3 -sulphate). These results suggest that the 17 -sulphate might be hydroxylated more readily than the 3,17-disulphate in vivo. $3 \alpha, 17 \beta$-Dihydroxy-5 $\alpha$-androstan-16-one was found in the disulphate fraction. This metabolite should be produced via formation of the 16hydroxysteroids. It is well documented that the $16 \beta$-hydroxy-17-oxosteroid is readily rearranged to the stable epimer, the $17 \beta$-hydroxy-16-oxosteroid, by means of alkali or acid, and by isolation procedure from urine. In order to examine the artifact formation during the isolation procedures, $3 \beta, 16 \beta$-dihydroxyandrost-5-en-17-one, a model compound, was treated similarly to the bile and analyzed by GC. $3 \beta, 16 \beta$-Dihydroxyandrost-5-en-17-one was entirely recovered by the procedures involving Amberlite XAD2, Sephadex LH-20, and solvolysis. However, separation by t.l.c. revealed the complete conversion of the $16 \beta$-hydroxy-17-oxosteroid to the $17 \beta$-hydroxy-16-oxosteroid. $3 \beta, 16 \alpha$ Dihydroxyandrost-5-en-17-one was not produced by these procedures. Furthermore, t.1.c. separation of $3 \alpha, 16 \alpha$-dihydroxy-5 $\alpha$-androstan-17-one showed partial epimerization to $3 \alpha, 17 \beta$-dihydroxy-5 $\alpha$-androstan-16-one. At present, we are unable to eliminate the possibility that $3 \alpha, 16 \beta$-diyhdroxy-5 $\alpha$-androstan-17-one (and $16 \alpha$-epimer) might be rearranged to the stable epimer during the isolation procudure. We hope that an investigation under way in this laboratory may clarify this problem. 
No.23 (1978)

In a previous paper, we reported large variations in biliary metabolites of androsterone in female rats. In rats with a high rate of biliary excretion of metabolites (HE rats), androsterone glucuronide was the predominant metabolite present in the bile. The results of the present study show that androsterone glucuronide was eliminated unchanged rapidly and exclusively in the bile. Thus, the injected androsterone must be predominantly conjugated with glucuronic acid in the $\mathrm{HE}$ rat probably due to high activity of the UDP-glucuronyltransferase system and/or low activity of sulphotransferase or hydroxylase enzymes and excreted in the bile. In rats with a low rate of biliary excretion of androsterone metabolites (LE rats), monosulphates of $3 \alpha, 7 \alpha$ - and $3 \alpha, 11 \beta$-dihydroxy-5 $\alpha$-androstan-17-ones were the major biliary metabolites, which were previously isolated from the pooled faeces of germfree rats. The present study demonstrates that androsterone sulphate was metabolized mainly to the monosulphate of $3 \alpha, 11 \beta$-dihydroxy-5 $\alpha$-androstan-17-one and disulphates of $5 \alpha$-androstane- $3 \alpha, 17 \beta$-diol and $3 \alpha, 17 \beta$-dihydroxy-5 $\alpha$-androstan-16-one. No production of $3 \alpha, 7 \alpha$-dihydroxy-5 $\alpha$-androstan-17-one monosulphate from androsterone sulphate should indicate that $7 \alpha$-hydroxylase enzyme might be active only on the free steroid. Contribution of the catabolic pathway of androsterone involving the initial conjugation with sulphuric acid in the LE rat was not clarified in this study. But, considerable difference in the metabolic pattern between androsterone and its sulphate suggests that this pathway is a minor one.

An investigation of the levels and activities of various enzymes involved in androsterone metabolism may be of interest for obtaining further insight into the regulatory mechanism responsible for large variations in androsterone metabolites in female rats. 